\title{
EXPERIMENTAL STUDIES OF THE MECHANISMS PRODUCING HYPOCALCEMIA IN HYPERNATREMIC STATES ${ }^{1}$
}

\author{
By LAURENCE FINBERG WITH THE TECHNICAL ASSISTANCE OF EVELYN FLEISHMAN \\ (From The Pediatric Division of the Baltimore City Hospitals and the Department of Pediatrics \\ of the Johns Hopkins School of Medicine, Baltimore, Md.)
}

(Submitted for publication August 27, 1956; accepted November 21, 1956)

That hypocalcemia may occur accompanying or following dehydration in infants has been stressed by Rapoport $(1,2)$. Several possible mechanisms have been suggested to explain this phenomenon. Rapoport considered the hypocalcemia part of the "post-acidotic syndrome" and thus a part of a readjustment phase following treatment. Hyperphosphatemia secondary to renal impairment could contribute to hypocalcemia as could rapid dilution of the extracellular fluid during therapy. A study of infants with hypernatremic dehydration revealed that hypocalcemia often appeared in this condition prior to therapy and that hyperphosphatemia was not a necessary concomitant (3). Further examination of the data suggested that the serum calcium concentration showed a roughly inverse correlation with the serum sodium concentration. Thus hypernatremia per se might be a major causative factor of this hypocalcemia. This report deals with an experimental approach to test the latter hypothesis.

\section{METHODS}

The experimental plan was to thirst young rats for a period and then inject sodium salts intraperitoneally; subsequently the animals were to be bled and analyses performed on serum and carcass for electrolytes.

The animals used in the experiments were male albino rats of the Wistar strain weighing between 100 and 200 grams and fed a standard diet. The composition of the diet was: casein, $250 \mathrm{gm}$., corn starch, $510 \mathrm{gm}$, vegetable oil, 149.5 gm., Brewer's yeast, 50 gm., U.S.P. salt mixture No. 14, 40 gm., and percomorph liver oil, 0.5 gm. The low potassium diet used in some of the experiments was obtained from Nutritional Biochemicals Corporation.

The intraperitoneal solutions injected ( $100 \mathrm{ml}$. per $\mathrm{Kg}$.) contained the following concentrations of ions in $\mathrm{mEq}$. per

1 Presented in part at the Society for Pediatric Research, Buck Hill Falls, Pa., May, 1956. Supported in part by the Research Fund of the Highlandtown Exchange Club of Baltimore.
L. (The designations used below will be continued in the text) :

$\begin{array}{llcccc} & & \mathrm{Na} & \mathrm{Cl} & \mathrm{HCO}, & \mathrm{K} \\ \text { Isotonic } & \mathrm{Na} & 150 & 120 & 30 & \\ \text { Hypertonic } & \mathrm{Na} & 300 & 240 & 60 & \\ \text { Hypertonic } & \mathrm{Na}+\mathrm{K} & 300 & 275 & 75 & 50\end{array}$

The rats were placed in metabolism cages for urine collection. Except where specified otherwise, the rats were thirsted 24 hours prior to injection and thereafter. A weighed amount of food was left available but it became apparent that the thirsting animals would not eat whether or not they received injections. The animals were sacrificed 24 to 48 hours following injection after anesthetizing with intraperitoneal sodium pentobarbital (50 mgm. per $\mathrm{Kg}$.) and obtaining blood from the abdominal aorta.

Serum was immediately separated from the red cells after clotting and chemical analyses subsequently performed. The chemical methods are those previously reported from this laboratory $(3,4)$. Sera and urines were analyzed for $\mathrm{Na}, \mathrm{Ca}, \mathrm{Cl}, \mathrm{K}$, Urea $\mathrm{N}$, and osmolarity. The latter determination was made using the Fiske osmometer. In addition $\mathrm{P}$, protein, $\mathrm{CO}_{2}$ content, and water determinations were performed on the serum. Calcium determinations throughout this study were performed by the method of Harrison and Harrison (5). Carcass analyses were performed by drying the skinned carcass to constant weight and then grinding the dried skin and carcass.

The resultant material was thoroughly mixed and duplicate aliquots were analyzed following ether extraction of the fat. Sodium and potassium were determined by flame photometry after dry ashing. Calculations of the extracellular concentrations of ions were made by correcting for serum water content and by multiplying cation and dividing anion concentrations by the Donnan factor of 0.96 . The carcass content of $\mathrm{Na}, \mathrm{K}$, and $\mathrm{Cl}$ are expressed as mEq. per $100 \mathrm{gm}$. of fat free solids. Tissue nitrogen is expressed as $\mathbf{~ g m}$. per $100 \mathrm{gm}$. of fat free solids. The chloride space (used as an approximation of extracellular fluid) is calculated from the total chloride content of the carcass and the extracellular chloride concentration.

In these experiments the intestinal tract and its contents were included in the carcass analyses in all groups. To assess the possible role of the intestinal content five control animals were analyzed after removal of intestines and compared to five animals simultaneously analyzed 
TABLE I

Results of analyses of sera and carcasses following intraperitoneal injection of hypertonic $\mathrm{Na}$ solution into thirsting animals

\begin{tabular}{|c|c|c|c|c|c|c|}
\hline \multirow[b]{2}{*}{$\begin{array}{c}\begin{array}{c}\text { Serum } \mathrm{Ca} \\
(\mathrm{mg} . / 100 \mathrm{mb} .)\end{array} \\
7.4 \\
7.5 \\
8.8 \\
8.6 \\
7.8 \\
8.3 \\
7.0 \\
7.9 \\
7.9 \\
8.4 \\
8.5\end{array}$} & \multirow[b]{2}{*}{$\begin{array}{c}\text { ECF Na } \\
(m E q . / L .) \\
166 \\
170 \\
159 \\
160 \\
189 \\
171 \\
174 \\
180 \\
161 \\
155 \\
176\end{array}$} & \multirow[b]{2}{*}{$\begin{array}{c}\text { Chloride space } \\
\text { (ml./100 gm. f.f.s.) } \\
119 \\
125 \\
126 \\
126 \\
128 \\
96.3 \\
101 \\
100 \\
119 \\
132 \\
121\end{array}$} & \multicolumn{2}{|c|}{$\underset{(m E q . / 100 \text { gm. f.f.s.) }}{\mathrm{Na}}$} & \multirow{2}{*}{$\begin{array}{c}\text { Carcass } \begin{array}{c}\mathrm{K} / \mathrm{N} \\
(\mathrm{mEq} . / \mathrm{gm} .)\end{array} \\
1.82 \\
1.72 \\
1.81 \\
1.93 \\
1.47 \\
1.57 \\
1.61 \\
1.64 \\
1.91 \\
1.65 \\
1.62\end{array}$} & \multirow[b]{2}{*}{$\begin{array}{c}\mathrm{Na} / \mathrm{K} \\
(m E q . / m E q .) \\
1.20 \\
1.04 \\
1.10 \\
1.21 \\
1.36 \\
1.01 \\
1.04 \\
1.06 \\
1.05 \\
1.12 \\
1.21\end{array}$} \\
\hline & & & $\begin{array}{l}30.2 \\
29.4 \\
25.4 \\
26.3 \\
27.8 \\
24.7 \\
24.7 \\
25.4 \\
24.4 \\
25.9 \\
27.8\end{array}$ & $\begin{array}{l}25.3 \\
28.4 \\
23.0 \\
21.8 \\
20.4 \\
24.6 \\
23.8 \\
24.0 \\
23.2 \\
23.1 \\
22.9\end{array}$ & & \\
\hline \multicolumn{7}{|c|}{ Average of 16 thirsting control animals } \\
\hline $\begin{array}{c}10.3 \\
\pm 0.21\end{array}$ & $\begin{array}{l}147 \\
\pm 3.1\end{array}$ & $\begin{array}{l}116 \\
\pm 3.0\end{array}$ & $\begin{array}{c}21.4 \\
\pm 0.22\end{array}$ & $\begin{array}{l}26.8 \\
\pm 0.26\end{array}$ & $\begin{array}{r}2.22 \\
\pm 0.05\end{array}$ & $\begin{array}{r}0.81 \\
\pm 0.05^{*}\end{array}$ \\
\hline
\end{tabular}

* Standard error of the mean.

in the usual fashion. No significant differences were found for $\mathrm{Na}, \mathrm{K}, \mathrm{Cl}$, or $\mathrm{N}$ content between the two groups. It should also be pointed out that the thirsting rats in the experiments cited had very little intestinal content when sacrificed.

\section{RESULTS}

Behavior changes in the thirsting rats were observed though they were not striking. The animals became somewhat withdrawn and lethargic but were hyper-irritable to stimuli. One animal of the sodium loaded group had some muscle twitchings which simulated tetany, but neither the hypocalcemia nor the other chemical derangements in this animal were more pronounced than in others studied. Animals receiving the low potassium diet failed to grow and appeared particularly listless and sick after intraperitoneal injection. In general the changes in behavior observed were not consistently different between thirsting controls and thirsting injected animals, hence such changes seemed largely attributable to thirsting alone.

Hypocalcemia could be regularly reproduced by the intraperitoneal injection of hypertonic sodium solution into thirsting rats. The thirsting state was chosen because in preliminary experiments with similar loads where the animals could drink after injection neither sodium excess nor hypocalcemia could be induced. The time of bleeding is of some importance in detecting hypocalcemia induced in this manner. Animals sacrificed 12 hours following injection did not have hypocal- cemia nor did a few surviving rats who were examined at more than 72 hours post injection. Hence the animals discussed herein were all examined between 24 and 48 hours post injection. The pertinent data on eleven such animals with carcass' analyses are presented in Table I and contrasted to the average values obtained from 16 uninjected, thirsting control animals. Though all of the injected animals are hypocalcemic the degree of hypocalcemia does not correlate with the degree of hypernatremia or of body sodium increase. Table II contrasts animals injected with the hypertonic $\mathrm{Na}$ solution with three types of controls: uninjected receiving water ad libitum, uninjected and thirsting, and thirsting animals injected with an equivalent volume of isotonic $\mathrm{Na}$ solution. The mean serum calcium values in the three control groups are in the normal range. There is no overlapping of calcium levels between

TABLE II

Effect of injection of hypertonic $\mathrm{Na}$ solutions $(100 \mathrm{ml}$. Kg.) on serum Ca

\begin{tabular}{|c|c|c|c|}
\hline $\begin{array}{l}\overline{\text { Number }} \\
\text { of } \\
\text { animals }\end{array}$ & Solution & Thirst hours & $\underset{(m g . / 100 ~ m l .)}{\text { Mean serum } C a}$ \\
\hline $\begin{array}{r}20 \\
12 \\
6\end{array}$ & $\begin{array}{c}\text { None } \\
\text { None } \\
\text { Isotonic } \mathrm{Na} \\
\text { (150 mEq./L.) }\end{array}$ & $\begin{array}{l}\text { None } \\
48 \text { to } 72 \\
48 \text { to } 72\end{array}$ & $\begin{array}{l}10.2 \pm 0.14^{*} \\
10.3 \pm 0.22 \\
10.2 \pm 0.23\end{array}$ \\
\hline 27 & $\begin{array}{l}\text { Hypertonic Na } \\
(300 \mathrm{mEq} . / \mathrm{L} .)\end{array}$ & 48 to 72 & $7.5 \pm 0.38$ \\
\hline
\end{tabular}

* Standard error of the mean. 
the hypertonic Na group and the other three and all of the calcium values are less than $9 \mathrm{mg}$. per $100 \mathrm{ml}$. in the group of experimental animals injected with hypertonic sodium solution. Total serum protein concentrations showed no differences among the various groups; the overall range was from 5.74 to $7.78 \mathrm{gm}$. per $100 \mathrm{ml}$. with an average of 6.49 gm. per $100 \mathrm{ml}$. These values did not differ significantly from unthirsted rats.

Thirsted but uninjected animals lost weight in the order of magnitude of 10 per cent of their initial weight and had very scanty (usually less than $1.5 \mathrm{ml}$.) urine output. The animals injected with hypertonic solutions showed slight but variable weight loss at 24 hours ( 1.0 to 6.0 per cent of initial weight) and put out urine volumes from 3.7 to $9.0 \mathrm{ml}$. in the first $24 \mathrm{hrs}$. When the experiments were carried to 48 hours the weight losses in the injected group approached those of the thirsted controls though the second 24-hour urine output diminished sharply in amount. The serum urea $\mathrm{N}$ concentration rose in all thirsted animals to about $40 \mathrm{mg}$. per $100 \mathrm{ml}$. and this concentration was roughly proportional to the length of the thirst. No intergroup differences were noted. Osmolarity determinations carried out on the sera paralleled the sodium concentration in these experiments and appear to add nothing to the data tabulated herein. Urine osmolarity determinations revealed the remarkable ability of the rat kidney to excrete a concentrated urine up to values to 3000 mOsm. per L. Among the animals injected with hypertonic solutions no inter-group differences in osmolarity were noted including the potassium deficient animals.

The extracellular sodium concentration in the experimental group was sometimes only slightly increased above control values. The carcass analyses however make it apparent that total body $\mathrm{Na}$ is consistently increased in these animals whereas in some control animals which have slight hypernatremia but without increased $\mathrm{Na}$ content, no hypocalcemia occurred. The mean carcass sodium in the experimental animals is $26.6 \mathrm{mEq}$. per 100 gm. f.f.s. in contrast to a mean of $21.4 \mathrm{mEq}$. per $100 \mathrm{gm}$. f.f.s. in the controls. The chloride space calculations showed no significant differences between hypocalcemic animals and controls. A third observation from the carcass data indicated a considerable potassium deficit in the sodium loaded hypocalcemic animals. The first two lines of Table III summarize these data. Control and experimental values for $\mathrm{K} / \mathrm{N}$ ratios are given to indicate the extent of the potassium deficits. The data suggest that the relative quantities of total body sodium and potassium might be important in determining the observed hypocalcemia. The $\mathrm{Na} / \mathrm{K}$ ratio which expresses this relationship increased from 0.81 in the controls to 1.13 in the experimental animals. This rise is the result of combined increase of sodium and decrease of potassium.

To test whether potassium deficiency alone might account for the hypocalcemia, rats were made potassium deficient by feeding a virtually potassium free diet for 21 days. This diet which

TABLE III

Comparison of mean serum and carcass analyses on controls, hypertonic $N a$ loads, $N a+K$ loads, $K$ deficiency, and $K$ deficiency plus hypertonic $N a$ loads

\begin{tabular}{|c|c|c|c|c|c|}
\hline$\underset{(\text { No. })}{\text { Animals }}$ & $\underset{(m g . / 100 ~ m l .)}{\text { Serum Ca }}$ & $\underset{(m E q . / L .)}{\mathrm{ECF} N a}$ & $\begin{array}{c}\text { Chloride space } \\
(m b . / 100 \mathrm{gm} . f . f . s .)\end{array}$ & $\underset{\left(m E_{q .} / g m .\right)}{K / N}$ & $\underset{(m E q . / m E q .)}{\mathrm{Na} / \mathrm{K}}$ \\
\hline Controls (16) & $10.3 \pm 0.21$ & $147 \pm 1.0$ & $116 \pm 3$ & $2.22 \pm 0.05$ & $0.81 \pm 0.05^{*}$ \\
\hline $\begin{array}{l}\mathrm{Na} \text { load- } \\
300 \mathrm{mEq} / \mathrm{L} \text {. } \\
100 \mathrm{ml} / \mathrm{Kg} . \\
(11)\end{array}$ & $8.0 \pm 0.17$ & $169 \pm 2.5$ & $117 \pm 3.8$ & $1.69 \pm 0.04$ & $1.13 \pm 0.03$ \\
\hline$\underset{(7)}{\mathrm{Na}}+\mathrm{K}$ loaded & $10.0 \pm 0.25$ & $160 \pm 1.1$ & $120 \pm 3.4$ & $2.38 \pm 0.04$ & $0.86 \pm 0.02$ \\
\hline K deficient (6) & $10.0 \pm 0.06$ & $147 \pm 1.4$ & $120 \pm 3.1$ & $1.75 \pm 0.04$ & $0.86 \pm 0.03$ \\
\hline $\begin{array}{c}\mathrm{K} \text { deficient plus } \\
\mathrm{Na} \text { load (8) }\end{array}$ & $7.6 \pm 0.12$ & $172 \pm 1.9$ & $116 \pm 3.3$ & $1.43 \pm 0.05$ & $1.43 \pm 0.05$ \\
\hline
\end{tabular}

* S.E.M. 
was also low in magnesium content contained 170 $\mathrm{mEq}$. of sodium per $\mathrm{Kg}$. The animals were thirsted for 24 hours and half the group were injected with the hypertonic $\mathrm{Na}$ solution. The last two sections of Table III compare these two groups of animals. The uninjected potassium deficient animals were not hypocalcemic, though the chloride spaces were on the average slightly greater than in the injected animals. The ratios of $\mathrm{K} / \mathrm{N}$ showed the expected decrease. The $\mathrm{Na} / \mathrm{K}$ ratios were only slightly increased over control animals fed the standard diet (Tables I and III) which may be due to the low magnesium content and the relatively low sodium content of the potassium deficient diet. Cotlove, Holliday, Schwartz and Wallace (6) found that when rats were fed a diet deficient in magnesium intracellular potassium deficit was not accompanied by an increased intracellular sodium such as occurs on a low potassium, high sodium diet. When the intraperitoneal hypertonic $\mathrm{Na}$ solutions were given to the potassium deficient animals hypernatremia and hypocalcemia occurred with concentrations of calcium uniformly less than $9 \mathrm{mg}$. per $100 \mathrm{ml}$; there was a further striking reduction in $\mathrm{K} / \mathrm{N}$ ratio; and finally the $\mathrm{Na} / \mathrm{K}$ ratio showed the expected marked increase. The experiment indicated that potassium deficiency without sodium excess was not responsible for the observed hypocalcemia.

To test whether sodium excess without potassium deficiency would result in hypocalcemia, another experiment was done in which potassium was added to the sodium loading solution. Seven rats receiving the stock diet were thirsted and injected with the hypertonic $\mathrm{Na}+\mathrm{K}$ solution. The second and third lines of Table III compare the results in these animals with those in which the hypertonic $\mathrm{Na}$ solution was given. The animals given added potassium were hypernatremic but not hypocalcemic; there were no significant differences in the chloride spaces between the two groups; the animals receiving $\mathrm{Na}+\mathrm{K}$ had normal or increased $\mathrm{K} / \mathrm{N}$ ratios; and the $\mathrm{Na} / \mathrm{K}$ ratio is nearly that of the controls despite an absolute increase in carcass sodium. The average value for this sodium was $28.5 \mathrm{mEq}$. per $100 \mathrm{gm}$. fat free solids, a clear cut increase over the control value of 21.4 in Table I.
No $\mathrm{pH}$ determinations were done in these experiments; however, $\mathrm{CO}_{2}$ content determinations showed no differences between thirsted controls and the hypertonic $\mathrm{Na}$ loaded animals. Values ranged from 16 to $20 \mathrm{mEq}$. per L. except in animals which had received the potassium free diet. In the latter animals $\mathrm{CO}_{2}$ levels ranged from 25.8 to $31.4 \mathrm{mEq}$. per $\mathrm{L}$. again with no differences between the hypertonic Na group and the "controls."

The influence of the serum phosphate concentration may be evaluated by the figure in which the concentration of serum calcium is plotted against the serum phosphorus level for these groups of animals: hypertonic $\mathrm{Na}$ loaded, hypertonic $\mathrm{Na}+\mathrm{K}$ loaded, and thirsting uninjected controls. As previously indicated the animals of the hypertonic sodium group show serum calcium concentrations which are all below $9 \mathrm{mg}$. per 100 ml. while the others are all greater than this level. On the other hand the serum phosphorus concentrations show considerable overlapping indicating it is not the causative factor for the differences noted in calcium.

Urine examination showed no quantitative differences in calcium excretion between hypocalcemic animals and control animals in those experiments where the experimental design resulted in similar urinary volume for the periods studied. Stools were scanty in all groups. Fecal calcium analyses in a few control and hypocalcemic rats revealed no differences.

\section{DISCUSSION}

This series of experiments suggests that an increase in body sodium in the rat will produce a temporary hypocalcemia, provided there is a concomitant body potassium deficiency; neither an excess of sodium nor a deficiency of potassium occurring independently produced this effect. In these experiments the hypocalcemic effect was seen only when the $\mathrm{Na} / \mathrm{K}$ ratio of the total body was 1.0 or greater. The predisposing effect of potassium deficiency in the development of hypocalcemia in rats following sodium loading has a possible counterpart in infants with hypernatremic dehydration. Rapoport, Dodd, Clark, and Syllm (1) described infants in the recovery phase of diarrheal disease who were hypocalcemic and hypokalemic. A number of the infants with hyper- 


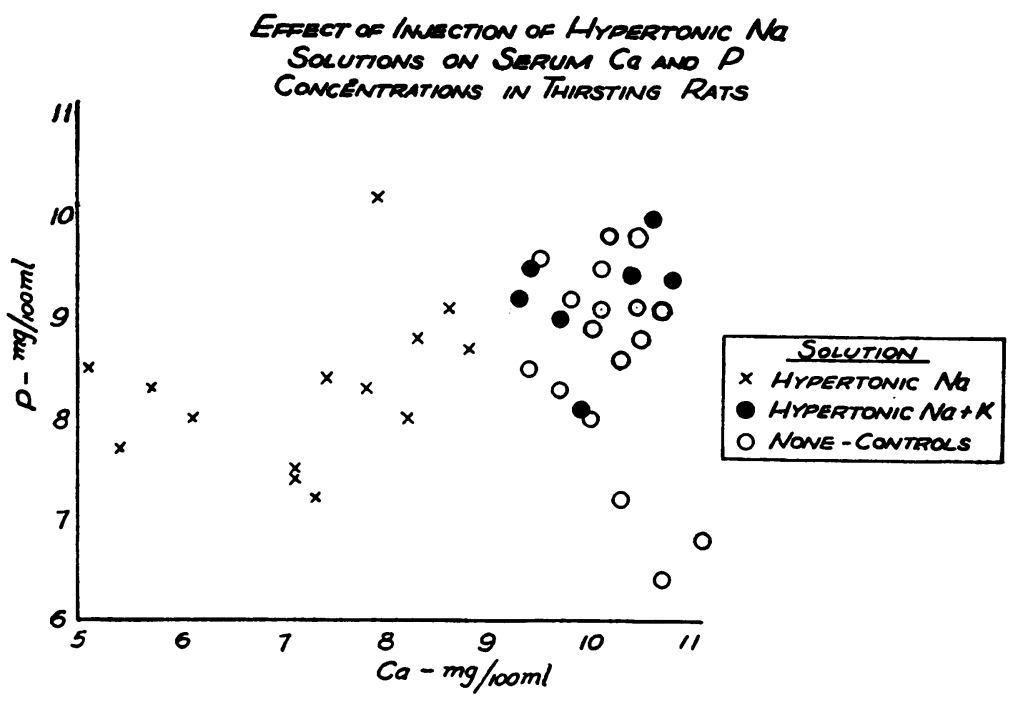

Figure 1

natremic dehydration studied by Weil and Wallace (7) as well as some of those studied in this clinic (3) had hypokalemia even during periods of marked urea nitrogen retention.

The infant with hypernatremic dehydration does not necessarily have hypocalcemia (3). While most such infants probably often have a reduced body sodium content it is possible that some may actually have sodium contents in excess of normal because of previous excessive dietary or therapeutic intake. At present it would be merely speculative to implicate an absolute sodium excess in such infants, or to say that these are the ones who become hypocalcemic. Some of the patients have become hypocalcemic after the administration of large amounts of sodium salts. Depletion of potassium which was found to be a necessary condition in the experimental animal for the occurrence of hypocalcemia seems a probable part of the usual picture of hypernatremic dehydration in the infant $(1,3,7)$. The mechanism whereby the potassium acts is not clear.

The concentration of calcium in the extracellular fluid is determined by a number of influences. In this study there appears to be no concern with the portion of calcium bound by serum protein since no differences in protein occurred among the various groups of animals. Changes in intestinal absorption seem unlikely to be significant since little or no food was ingested by the rats once the thirsting period began. Excretion of calcium in the urine showed no differences between the hypocalcemic animals and the others. Thus rapid calcium excretion also seems unlikely to be a factor in this study.

The data suggest that the effect demonstrated by this study results from an alteration in the equilibrium point of the balance between extracellular calcium and the skeletal calcium. The steady state between dissolved calcium and calcium of bone salt probably involves cellular activity of skeletal tissue as well as a physico-chemical equilibrium between solution and solid phases. Parathyroid hormone and vitamin D probably influence the cellular activity involved, but the present data are not adequate to show whether the effect might be mediated through a disturbance in those systems. Sodium is considered to accumulate on the surfaces of bone crystals and this sodium is known to act as a sort of flexible sodium reservoir under conditions of physiologic disturbances of electrolyte equilibrium $(8,9)$. Sudden increases in sodium content of bone surface may well play an interfering role in the maintenance of calcium homeostasis. No data bearing on this point are contained in the present study. Moreover the "protective" role of the potassium would be difficult to explain since the sodium content of the $\mathrm{Na}+\mathrm{K}$ loaded animals is as high as those loaded with hypertonic $\mathrm{Na}$. Additional experiments are needed to further elucidate the mechanisms involved. 


\section{SUMMARY AND CONCLUSIONS}

Thirsting rats injected with hypertonic sodium solution become hypocalcemic concomitant with a rise in total body sodium and a fall in body potassium. Neither extracellular dilution nor phosphate retention were important factors in producing this effect. Sodium excess alone or potassium deficiency alone does not result in the hypocalcemia. The total body sodium was equal to or greater than the total body potassium (measured in milliequivalents) in the animals which developed hypocalcemia. It is suggested that the hypocalcemia results from an alteration in equilibrium between extracellular and skeletal calcium.

\section{REFERENCES}

1. Rapoport, S., Dodd, K., Clark, M., and Syllm, I., Postacidotic state of infantile diarrhea; symptoms and chemical data. Am. J. Dis. Child., 1947, 73, 391.
2. Rapoport, S., Hyperosmolarity and hyperelectrolytemia in pathologic conditions of childhood. Am. J. Dis. Child., 1947, 74, 682.

3. Finberg, L., and Harrison, H. E., Hypernatremia in infants. An evaluation of the clinical and biochemical findings accompanying this state. Pediatrics, $1955,16,1$.

4. Harrison, H. E., Finberg, L., and Fleishman, E., Disturbances of ionic equilibrium of intracellular and extracellular electrolytes in patients with tuberculous meningitis. J. Clin. Invest., 1952, 31, 300.

5. Harrison, H. E., and Harrison, H. C., A micromethod for determination of serum calcium. J. Lab. \& Clin. Med., 1955, 46, 662.

6. Cotlove, E., Holliday, M. A., Schwartz, R., and Wallace, W. M., Effects of electrolyte depletion and acid-base disturbance on muscle cations. Am. J. Physiol., 1951, 167, 665.

7. Weil, W. B., and Wallace, W. M., Hypertonic dehydration in infancy. Pediatrics, 1956, 17, 171.

8. Bergstrom, W. H., and Wallace, W. M., Bone as a sodium and potassium reservoir. J. Clin. Invest., 1954, 33, 867.

9. Bergstrom, W. H., The participation of bone in total body sodium metabolism in the rat. J. Clin. Invest., 1955, 34, 997. 